\title{
The Africa Mining Vision: A Panacea to the challenges of the African mining sector or another mirage?
}

\author{
Penda Diallo*
}

The Africa Mining Vision envisages 'transparent, equitable and optimal exploitation of mineral resources to underpin broad-based sustainable growth and socio-economic development'. ${ }^{1}$

Africa is one of the regions endowed with the world's largest reserves of minerals including bauxite, diamonds, iron ore, gold, platinum, chromite, manganese and vanadium. ${ }^{2}$ As early as the 1980 s this sector was identified as a key source for socio-economic growth. In an attempt to increase the contribution of the sector to socio-economic development, the World Bank (WB) and International Monetary Fund (IMF) implemented a number of economic and political reforms and initiatives in resource rich African countries from the mid-1980s to the 1990s. These reforms were meant to attract Foreign Direct Investment (FDI) and contribute to socio-economic development and they led to the liberalization of economies and the privatization of the mining industry across Africa ${ }^{3}$.

However, the results and consequences of reforms led by the WB and IMF were disappointing. The liberalization of the African economy in the 1980s and 1990s did increase FDI, especially in resource-rich countries, but while it increased the production of most minerals and the profit of mining companies, it did not result in the predicted socio-economic development of local populations. ${ }^{3}$ The reforms relegated the role of African governments to a purely administrative one, thus leading to a lack of control of the mining sector by African leaders. The minimizing of state involvement in the mining sector meant there was no space for the reforms to either build the state's institutional capacity or develop the state's involvement in the effective

\footnotetext{
${ }^{1}$ AU-African Union (2009), Africa Mining Vision, (Addis Ababa: AU)

2 Bush, R.C (2008), 'Soon There Will be No-one Left to Take the Corpses to the Morgue: Accumulation and Abjection in Ghana's mining Communities'. Resources Policy. 34 (1-2), pp. 57-62

${ }^{3}$ Campbell, B (Ed.) (2004), Regulating Mining in Africa - For Whose Benefit?, Discussion Paper No. 26, (Uppsala: Nordiska Afrikainstitutet); Graham, Y (2013). Escaping the Winner's Curse: The Africa Mining Vision and the Challenges of the International Trade and Investment Regime, Workshop on International Law, Natural Resources and Sustainable Development, September 11-13 September 2013, Third World Network Africa, Accra
} 
implementation of the reforms. ${ }^{3}$ Additionally, the benefit of mining to local communities was limited to a few examples of developments of the informal economy in areas around mining 'enclaves'.

Although attempts had been made to address challenges presented by African the mining sector, by 2008 none had been fully successful in ensuring that mining contributed to sustainable socio-economic growth in Africa. As a result, a new initiative called the Africa Mining Vision (AMV) was launched by the African Union in 2008 and adopted by African Heads of States and Governments in February 2009.

The AMV is 'Africa's own response to tackling the paradox of great mineral wealth existing side by side with pervasive poverty'. ${ }^{4}$ The adoption of the AMV is a major initiative for Africa by African leaders: this is the first time that African leaders, rather than external actors, had developed an initiative to improve the conduct of the mining sector. The willingness of African leaders to come together showed the serious nature of the need to improve the sector. It was also the first step toward collective leadership on this issue, demonstrating at least in principle the commitment of African leaders to transforming the situations in their countries and communities. In essence, a strategic vision was being articulated at continental level that could alter policy at country level as well as practice on the ground toward changing things for the better for local society.

The AMV takes a holistic approach, integrating mining into national policies and ensuring that mining contributes to sustainable development. ${ }^{5}$ It promotes small-scale mining, better environmental policies, institutional and human capacity-building, good governance, transparency and accountability, with the aim of adding value to mineral resources before exporting them and developing economic linkages between mining activities and the domestic economy. ${ }^{6}$ Thus, it prioritizes local development rather than attracting private

\footnotetext{
${ }^{4}$ UNECA-The United nations, Economic Commission for Africa. (n.d), About the Africa Mining Vision, (Addis Ababa: UNECA)

5 UNECA-The United Nations Economic Commission for Africa (2014), Minerals Centre produces Guidebook for Domestication of African Mining Vision, (Addis Ababa: UNECA) 6 UNECA-The United Nations Economic Commission for Africa (2008). Africa Review Report on Mining - Executive Summary, (Addis Ababa: UNECA)

AU (2009)

ACEP-Africa Centre for Energy Policy (2014), A Guide to the Africa Mining Vision (AMV), (Accra: ACEP)
} 
mining companies as was the case with previous reforms undertaken by the WB and IMF. ${ }^{7}$

Eight years after adopting the AMV, despite its objective of transforming the African mining sectors, not much has changed. The challenges still facing the African mining sector include issues of transparency and accountability, governance and public participation; the environmental, economic, social and health impacts of its operation; its failure to add value, and its failure to provide benefits relating to research, development and technological information. In addition, there are unresolved problems relating to artisanal and small-scale mining and there is an urgent need to build the human and institutional capacities of state institutions. ${ }^{8}$

While an increasing number of industrial mining companies have been operating across the continent, socio-economic growth for the larger population is yet to follow. Countries rich in natural resources including Guinea, Niger, Sierra Leone, Nigeria, Equatorial Guinea and Chad still have a majority of their populations living in extreme poverty with high rates of unemployment. These countries still suffer from corruption that limits the ability of most citizens to benefit from mining revenues. In Guinea, for example, more than $50 \%$ of the population still lives in poverty and much of the population of the country lacks access to clean drinking water, health centres, electricity and roads. ${ }^{9}$

The AMV is yet to show any positive impacts either at the level of policy or actions on the ground. The reasons why the AMV has not yielded any results can be linked to the fact that since its launch in 2008, there needed to be some preparatory work within the African Union in order to support the implementation of the AMV vision. One of the efforts toward the preparation for effective implementation of the AMV was the creation of the African Mineral Development Centre (AMDC) in 2011. In 2014 the AMDC put together a guidebook to ensure that the objectives of the AMV would be effectively promoted at country levels and that member States would align their policies and objectives with those of the AMV. ${ }^{5}$ Hence, between 2008 and 2015, efforts

\footnotetext{
${ }^{7}$ Bush, R. \& Graham. Y (2010), Mining Companies Are Not Interested in Africa's Development. The Guardian. Available from: http://www.theguardian.com/business/2010/dec/02/euraw-materials-initiative-africa-mining [Accessed on 29 December 2015]

8 Bush (2008), pp4-7

${ }_{9}^{9}$ AEO-African Economic Outlook (2015), Guinea, http://www.africaneconomicoutlook.org/en/country-notes/west-africa/guinea/. [Accessed on 29 December 2016].
} 
seemed to have been invested in putting together needed and substantive measures that would support the effective implementation of the AMV. Although these are commendable efforts, eight years would seem to represent a long time to wait for a vision to be implemented. It is now time for African leaders to move the AMV from a simple vision and transform it into practical action. There is an urgency to move to the implementation phase of the objectives set out by the AMV before the momentum that led to its creation is lost.

Despite the delay in producing any positive results for the wider society across mineral resource rich countries in Africa, there are still opportunities for the AMV to make positive contributions. There are several reasons why there is still space for such positive contributions. First, anecdotal evidence suggests that African leaders and their states have shown a willingness to support the vision. Second, mining companies and their host states are under pressure from the broader population to ensure that profits from mining reach the wider society. Hence an improvement in the African mining sector so that it is beneficial to all stakeholders has now become a necessity for the stability of mining activities in Africa.

Previous mining initiatives have not succeeded in effectively addressing issues in the artisanal and small-scale mining sector or ensuring that mining revenues are linked to the wider local economy. ${ }^{2}$ Many issues need to be addressed to ensure that the AMV is a successful solution to the challenges presented by the African mining sector. In practice, socio-economic development resulting from the activities of the mining sector cannot be accomplished without building the resource rich states' institutional capacity to implement, promote and monitor reforms within the mining sector. Additionally, successful mining activities can only be achieved if local communities feel that they would benefit from mining projects.

\section{How the AMV can improve institutional capacity at country-level}

In the majority of African countries, the most urgent need is to increase the human and institutional capacity of country-level stakeholders to implement, monitor and address the issues associated with mineral resource extraction. The following four points are crucial for the AMV in addressing the capacitybuilding challenges across the continent and thus becoming the solution that it hopes to be, rather than a mirage of empty promises.

The first is to effectively build the capacity of governments to design and enforce viable environmental and development-sensitive mining policies. 
Perhaps in part because of its contribution to employment and to the informal economy, the environmental impact of mining remains a major challenge, which is yet to be adequately addressed in most African countries. ${ }^{2}$ Although most African countries have environmental legislation, this is often not enforced. In countries such as Guinea, Sierra Leone and Liberia, mining has posed real development and environmental challenges. Agricultural lands are used as mining sites and once mining is finished, there is no effort to make the land viable for agriculture once again. Capacity-building ideas could include assisting governments to design and implement viable, environmentally sensitive mining policies. These policies could, for instance, include the transformation of waste mining sites to viable agricultural land, which would provide sustainable livelihoods for rural communities. In this way, livelihoods would be sustained even after mining activities have ceased. Thus, African governments need to develop the skills, legislation, culture and will to regulate mining companies working on the continent and to ensure that penalties are paid by those polluting the environment or putting at risk the health of local citizens.

Second, African governments need to develop their ability to capture artisanal mining revenue in the formal economy; many are currently unable to do so. The additional revenues from the ASM sector would give governments further incentive to focus on artisanal mining communities and support their socioeconomic development.

Third, non-governmental organisations (NGOs) need to develop their ability to campaign and advocate for better mining policies and operations, and to alert and educate communities about environmentally sensitive approaches to mining. Stronger and more capable grassroots NGOs would be able to hold governments to account for their policies and advocate policies and practices leading to sustainable economic development and environmentally sensitive mining.

Fourth, the Free Prior and Informed Consent (FPIC) principle should be respected in all countries during the development of mining projects. FPIC is 'the principle that indigenous peoples and local communities must be adequately informed about oil, gas and mining projects in a timely manner and should be given the opportunity to approve (or reject) a project prior to the commencement of operations'.10 Mining companies and governments are

\footnotetext{
10 Voss, M. \& Greenspan. E. (2012). Community Consent Index: Oil, Gas and Mining Company Public Positions on Free, Prior, and Informed Consent (FPIC), Oxfam America Research Backgrounder series, p.7
} 
facing ongoing pressure from communities demanding to be engaged in decisions regarding their land. This means both government and mining companies need to ensure that local communities are involved in and approve decisions affecting their lands in order to avoid any disruption to mining activities, once they start.

If the AMV continues to take longer in delivering on its promises, we will see more community-led protests on mining sites; creating further instability in the mining sector and less profit for private companies as well as lower revenues for mineral resource rich states. Mining will only be successful where stability of production can be ensured, but this can only be guaranteed with the support of the local communities. With the internet and the growing role of NGOs in the African mining sector, local communities know that they no longer have to be passive victims; rather they can be actors bringing change to their communities. So far, this has only been achieved through protests at mining sites. It would have been much more positive and productive if measures had already been in place to ensure that the benefits of mining activities are spread beyond mining 'enclaves'.

The success of the AMV will depend on the ability of African leaders to ensure that gaps in the human resource and institutional capacity in specific countries are filled. Populations in mineral resource-rich countries are becoming impatient and frustrated, and the AMV needs to meet their legitimate socioeconomic expectations that mining revenues should benefit local communities and contribute to socio-economic development in their country as a whole. To prevent further social instability generated by the extractive industry in Africa, the AMV must make its mark, and make it very soon.

*Senior Resilience Advisor with CARE in London

\section{BIBLIOGRAPHY}

ACEP-Africa Centre for Energy Policy (2014), A Guide to the Africa Mining Vision (AMV) (Accra: ACEP)

AEO-African Economic Outlook (2015), Guinea http://www.africaneconomicoutlook.org/en/country-notes/westafrica/guinea/. [Accessed on 29 December 2016]

AU-African Union (2009), Africa Mining Vision (Addis Ababa: AU)

Bush, R. \& Graham. Y (2010), Mining Companies Are Not Interested in Africa's Development. The Guardian. Available from: 
http://www.theguardian.com/business/2010/dec/02/eu-raw-materialsinitiative-africa-mining [Accessed on 29 December 2015]

Bush, R.C (2008), 'Soon There Will be No-one Left to Take the Corpses to the Morgue: Accumulation and Abjection in Ghana's Mining Communities'.

Resources Policy. 34 (1-2), pp. 57-62

Campbell, B., (Ed.) (2004). Regulating Mining in Africa - For Whose Benefit? Discussion Paper No. 26, (Uppsala: Nordiska Afrikainstitutet)

Graham, Y. (2013), Escaping the Winner's Curse: The Africa Mining Vision and the Challenges of the International Trade and Investment Regime, Workshop on International Law, Natural Resources and Sustainable Development, September 11-13 September 2013, Third World Network Africa, Accra

UNECA-The United Nations Economic Commission for Africa (2008). Africa Review Report on Mining - Executive Summary. (Addis Ababa: UNECA)

UNECA-United Nations Economic Commission for Africa (2014), Minerals Centre produces Guidebook for Domestication of African Mining Vision (Addis Ababa: UNECA)

UNECA-United nations, Economic Commission for Africa ( n.d), About the Africa Mining Vision (Addis Ababa: UNECA)

Voss, M. \& Greenspan. E (2012), Community Consent Index: Oil, Gas and Mining Company Public Positions on Free, Prior, and Informed Consent (FPIC), Oxfam America Research Backgrounder series 